\title{
"Australia is one of the darkest markets in the world": the global importance of Australian tobacco control
}

\author{
S Chapman, F Byrne, S M Carter,
}

\begin{abstract}
"Australia is one of the darkest markets in the world... it probably is the darkest, I mean ourselves and Canada fight every month for who's got the darkest conditions to do tobacco manufacturing and marketing. And one of the things we can offer the world is what we do best, which is how to work, maximize, proactively drive our market position in a market that's completely dark. Now that takes a different skillset... a different type of learning. We need to export that... we know we have a lot of expatriates who come down to Australia for learning... they can come here and learn these techniques and take them back to Europe or Latin America or to the United States or to Africa... But the other thing that is really good for us is that we are also a huge net exporter of Australian talent... about 30 or 40 people currently off-shore... We do things really differently here than most other BAT organizations." David Crowe, Marketing Director, British American Tobacco (BAT) Australia'
\end{abstract}

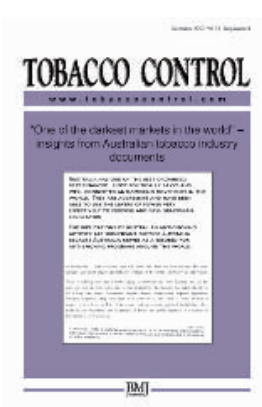

See end of article for authors' affiliations

.....................

Correspondence to: Professor Simon Chapman, School of Public Health, University of Sydney, Building A 27, Sydney, NSW 2006, Australia; simonchapman@ health.usyd.edu.au
Tobacco Control 2003;12(Suppl III):iii1-iii3

fighting, dirty tricks by the opposition, and all manner of hassle and public argument is a feature of the business in Australasia." ${ }^{\prime 3}$

- "Australia is a laboratory for the global antismoking network. Both anti-smoking policies and the individuals who promote them are exported from Australia and stimulate antismoking activities worldwide". ${ }^{4}$

- "Within this group [the leadership of the international tobacco control activist movement] the Australians play a prominent role." ${ }^{\prime 5}$

In 1994, BAT named Australia as one of six nations and regions that were "driving tobacco control" $^{\prime 6}$ and in 1997 RJ Reynolds referred to likely regulatory developments in the USA as "an outgrowth of what was put in place in other countries" naming Australia. ${ }^{7}$

In the past three decades, Australian tobacco control has made significant gains in the following areas:

- Australia was among the first nations to test tar and nicotine content of cigarettes and to publicly advocate the potential significance of tobacco yield data for harm reduction. ${ }^{8}$

- Australia was one of the first democracies to ban all forms of tobacco advertising and sponsorship.

- Along with Brazil, Canada, New Zealand, Poland, South Africa and Thailand, Australia was among the first nations to introduce large and disease explicit pack warnings. ${ }^{9}$ The introduction of these warnings saw prolonged periods of fierce lobbying by the industry against their implementation, fearing an international domino effect.

- Commencing in the late 1970s, Australia was one of the first nations to run large scale, state sponsored mass reach national public awareness anti-smoking campaigns. ${ }^{10-12}$ These campaigns were attacked by the tobacco industry and some were removed by an industry dominated self regulatory process. ${ }^{13}$ Australia was the first nation to experience widespread civil disobedience against the tobacco industry in the form of a five year campaign where doctors and other health workers put graffiti on tobacco billboards. ${ }^{14}$ There is considerable animated discussion of this in the industry's documents.

- Australia has long had a highly networked national tobacco control advocacy movement and their track record of achievement stands as a model for other nations in how to reduce tobacco use. ${ }^{15}$ Daily smoking prevalence for 
Australians aged 14 and over is currently $19.5 \%$, one of the lowest in the world. ${ }^{16}$

- In 1986, the state of South Australia was the first nation to ban small "kiddie" packs $(<20$ sticks $) .{ }^{17}$ This ban subsequently went national.

- Australia has relatively high tobacco tax by international standards, ${ }^{18}$ with there being many episodes of industry lobbying to restrain further rises.

- The Australian state of Victoria pioneered the use of tobacco tax hypothecation to enable the buy-out of tobacco sponsorships ${ }^{19}$ - something which then proliferated internationally and which the industry said "must [be] stop[ped $]^{\prime \prime} .^{20}$

\section{INDUSTRY DOCUMENTS}

The inside history of industry reaction and opposition to each of these-and many more-issues is covered extensively in the industry documents released since 1998 under the terms of the Master Settlement Agreement (MSA). ${ }^{21}$ Our application to the US National Cancer Institute and the Australian National Health and Medical Research Council for funding for this project stressed the importance of passing knowledge to public health workers in other nations about the tobacco industry's conduct in seeking to delay and defeat effective tobacco control. To be forewarned is to be forearmed, and we hope the light we have thrown on a wide range of industry conduct will be useful in derailing such conduct in other nations. Because Australia was feared by the industry to be a bellwether $^{22}$ or "lead domino" nation in a potentially unstoppable cascade toward tobacco control, it was accorded high priority by the industry's transnational headquarters. Our paper on the panic to stop strong health warnings being accepted in Australia ${ }^{9}$ is a particularly strong illustration of this.

We also produced the supplement to help a particular Australian readership: sick and dying litigants and their lawyers seeking chronicles of mendacious industry conduct designed to reassure smokers that they need not seriously consider stopping smoking and governments that they should not introduce controls on tobacco. One person who inspired us greatly during this project was the late Rolah McCabe (1950-2002), the gravely ill woman shown in fig 1 . Rolah commenced smoking at the age of 14 and in 2002 while she was dying from lung cancer 30 years before the average life expectancy she might have enjoyed for a woman of her age, sued BAT Australia for misleading and deceptive conduct. The trial judge found evidence of wholesale

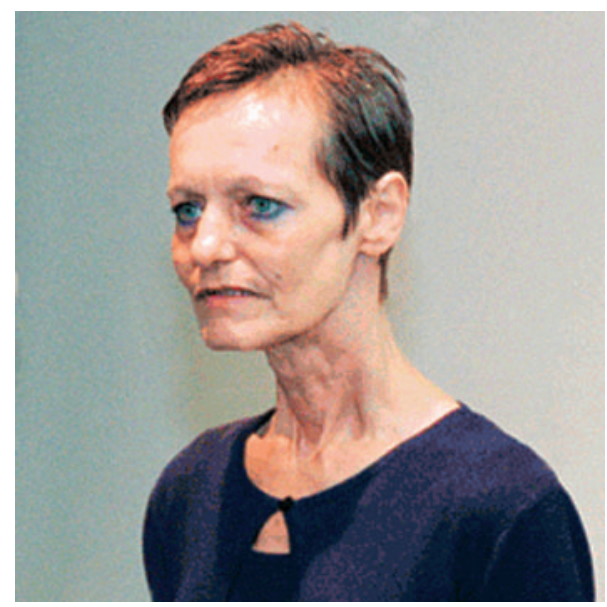

Figure 1 Rolah McCabe (1950-2002). document destruction within the company, which he argued prevented Ms McCabe from obtaining a fair trial. ${ }^{23}{ }^{24}$

Rolah McCabe stated on many occasions that her primary motivation in taking BAT to court was to set a legal precedent in Australia that would bring justice to thousands of others like her who, as children, had taken up smoking in eras when the industry ran riot with both advertising and denial of harm campaigns. In the last months of her life, Rolah showed astonishing bravery and leadership in taking the action she did.

\section{HOW WE FOUND THE DOCUMENTS}

The documents cited in these papers were located from searches conducted on the MSA websites of Philip Morris, RJ Reynolds, Lorillard, The Tobacco Institute, The Council for Tobacco Research, Brown \& Williamson, and the American Tobacco Company between May 2001 and January 2003.

To facilitate systematic document analysis, the preliminary search strategy focused on retrieving documents using key Australian geographic terms such as Australia, Australian cities and tobacco manufacturing sites (see http://tobacco.health. usyd.edu.au/site/gateway/docs/pdf/Aust_Search_Strategy.pdf).

Documents retrieved by these searches were sorted into broad topic areas and evaluated by the research group according to their perceived degree of importance. Researchers maintained an Excel workbook divided into 20 thematic worksheets to record interpretive information (see http://tobacco.health.usyd.edu.au/site/gateway/docs/pdf/ Aust_Search_Strategy.pdf).

Throughout the evaluation process, the metadata for documents considered to be of high value were screened for further clues to conduct subsequent searches. Opportunistic searches were conducted on both the primary MSA websites and secondary document collections (Tobacco Documents Online and other sites providing access to BAT documents) based on themes identified as critical. Search words incorporated synonymous terms representative of the concept, acronyms, abbreviations, and variations of spelling. ${ }^{25}$ (see http://tobacco.health.usyd.edu.au/site/gateway/docs/pdf/ Aust_Search_Strategy.pdf).

\section{LIMITATIONS}

There are three main limitations of research undertaken for this project:

- Of the volume of documents released via the MSA only a small proportion were documents created in Australia. Those thus located are not assumed to be a complete representation of all Australian documents.

- Limited access to BAT documents. The MSA website provision did not apply to BAT and only a small subset of documents has so far been made available on the internet by researchers who have requested documents direct from the Guildford Depository and digitised them.

- Document destruction. Because of large scale document destruction, the documents available represent an unknown cross section of all documents ever written and circulated within the tobacco industry. In 1992, BAT's head of group security wrote about document destruction throughout the company: "in determining whether a redundant document contains sensitive information holders should apply the rule of thumb of whether the contents would harm or embarrass the Company or an individual if they were to be made public or to reach the competition." ${ }^{26}$ When asked "And one of the benefits of limiting such retention was that documents would not fall into the hands of plaintiffs or the public or the newspapers, right?" a former lawyer for BAT's US affiliate Brown \& Williamson stated in a deposition to the US 
Department of Justice in August 2002: "That was the... purpose of the mental copy rule and the program as a whole." ${ }^{27}$ Philip Morris also had a major document destruction programme. ${ }^{28}$

\section{Missing documents}

When searching the documents, it has been very common to locate a small number of documents describing particular events and concerns in Australia, but which when followed up in document searching based on the issues being discussed or individuals named then "dry up", with only fragmentary pictures emerging of more complete episodes. Whether through deliberate, strategic document destruction programmes or through more innocent "housekeeping" practices, many documents are plainly missing.

Like us, readers will sometimes want to ask more about an episode being described. Where possible, we have located the fragments available within the contexts provided by other sources and our own experience of events where we lived through the events being described. In this, our accounts differ little from any historical record where incomplete documentation is available.

\section{AVAILABILITY OF DOCUMENTS}

Researcher's annotations and the accompanying documents are available for searching on the Tobacco Control Supersite at http://tobacco.health.usyd.edu.au/site/gateway/ docs/search.htm.

\section{ACKNOWLEDGEMENTS}

The research reported in this supplement was supported by grants from the National Health and Medical Research Council (2001-2003 \#153857) and the US National Institutes of Health (2001-2005 \# R01 CA87110-01Al).

\section{Authors' affiliations}

S Chapman*, F Byrne, S M Carter, School of Public Health, University of Sydney, New South Wales, Australia

\section{*Also Associate Director, VicHealth Centre for Tobacco Control}

\section{REFERENCES}

1 British American Tobacco Australasia. The challenge of change [CD ROM for internal company use]. Sydney: British American Tobacco Australasia, 2001.

2 Philip Morris. Corporate Affairs plan: Philip Morris (Australia) Limited. 19 Oct 1992. Philip Morris. Bates No. 2023240608/0627. http:// legacy.library.ucsf.edu/tid/fgw48e00

3 Turner A. Asian Tobacco Council. Tobacco: the battle for social acceptance: [speech given to the Sixth World Tobacco Exhibition \& Symposium at the Vienna Messelgelande, Austria, 22-25 October 1990]. 22 Oct 1990; R.J. Reynolds. Bates No. $511970081 / 0100$. http://legacy.library.ucsf.edu/tid/ mfk43d00

4 Philip Morris. Draft plan. 1993. Philip Morris. Bates No. 2504200150. http://legacy.library.ucsf.edu/tid/imi29e00

5 Philip Morris. [Boca Raton Action Plan, Appendix A: WHO/IOCU/UICC: Strategies and Tactics]. 31 Jan 1989. Philip Morris. Bates No. 2021595780/ 5784. http://legacy.library.ucsf.edu/tid/asp44e00

6 Proctor C. Smoking issues. Sep 1994. British American Tobacco. Bates No. 502581860/1870. http://tobacco.health.usyd.edu.au/tds/ BAT502581860 1870 (Accessed 19 Sep 2003).
7 Stockdale B. Australia trip: topline learning (highly restricted market). 12 Feb 1997. R.J. Reynolds. Bates No. 518093846/3852. http:// legacy.library.ucsf.edu/tid/ads90d00

8 King W, Carter SM, Borland R, et al. The Australian tar derby: the origins and fate of a low tar harm reduction programme. Tobacco Control 2003; 12(suppl III):iii61-70.

9 Chapman S, Carter SM. "Avoid health warnings on all tobacco products for just as long as we can": a history of tobacco industry efforts to avoid, delay and dilute health warnings on cigarettes. Tobacco Control 2003;12(suppl III):iii13-22.

10 Egger G, Fitzgerald W, Frape G, et al. Results of large scale media antismoking campaign in Australia: North Coast "Quit for Life" programme. BMJ Clinical Research Ed 1983;287:1125-8.

11 Pierce JP, Dwyer T, Frape G, et al. Evaluation of the Sydney "Quit. For Life" anti-smoking campaign. Part 1 . Achievement of intermediate goals. Med J Aust 1986;144:341-4.

12 Centre for Behavioural Research in Cancer, Anti-Cancer Council of Victoria. Quit Evaluation Studies Volume 9. Melbourne: Anti-Cancer Council of Victoria, 1998; http://www.quit.org.au/quit/QE9/ QE9Home.html (Accessed 19 Sep 2003).

13 Carter S, Chapman SM. Smoking, disease, and obdurate denial: the Australian tobacco industry in the 1980s. Tobacco Control 2003;12(suppl III):iii23-30.

14 Chapman S. Civil disobedience and tobacco control: the case of BUGA UP. Tobacco Control 1996:5:179-85.

15 Chapman S, Wakefield M. Tobacco control advocacy in Australia: reflections on 30 years of progress. Health Educ Behav 2001;28:274-89.

16 Australian Institute of Health and Welfare. 2001 National Drug Strategy Household Survey: State and Territory supplement. AlHW cat. no. PHE 37. Canberra: AlHW, 2002:3 (Drug Statistics Series No. 10). http:// www.aihw.gov.au/publications/phe/ndshs01 sts/ndshs01 sts.pdf (Accessed 19 Sep 2003).

17 Wilson D, Wakefield M, Esterman A, et al. 15s: they fit in everywhereespecially the school bag: a survey of purchases of packets of 15 cigarettes by 14 and 15 year olds in South Australia. Community Health Studies 1987;11(suppl 1):16s-20s.

18 Scollo M, Sweanor D. Cigarette taxes. Tobacco Control 1999:8:110-11.

19 Holman CD, Donovan RJ, Corti B, et al. Banning tobacco sponsorship: replacing tobacco with health messages and creating health-promoting environments. Tobacco Control 1997;6:115-21.

20 Bible G. Corporate Affairs Conference/Action Plan. 13 Dec 1988. Philip Morris. Bates No. 2021596422/6432. http://legacy.library.ucsf.edu/tid/ izf58e00.

21 National Association of Attorneys General. Master Settlement Agreement. http://www.naag.org/upload/ 1032468605_cigmsa.pdf (Accessed 4 Feb 2003).

22 Maxwell H. Draft speech for Hamish Maxwell marketing meeting, 24 June. 24 Jun 1983. Philip Morris. Bates No. 2021285680/5697. http:// legacy.library.ucsf.edu/tid/nyz24e00

23 McCabe v British American Tobacco Australia Services Limited [2002] VSC 73 (22 March 2002). hitp://www.austlii.edu.au/au/cases/vic/VSC/2002/ 73. html (Accessed 19 Sep 2003)

24 Liberman J. The shredding of BAT's defence: McCabe $v$ British American Tobacco Australia. Tobacco Control 2002;11:271-4.

25 Malone RE, Balbach ED. Tobacco industry documents: treasure trove or quagmire? Tobacco Control 2000;9:334-8.

26 Thomas A. Destruction of classified documents. 15 Dec 1992. British American Tobacco. Bates No. 500173752. http:// tobacco.health.usyd.edu.au/tds/BAT500173752 (Accessed 19 Sep 2003).

27 Shiel F. Lawyer admits tobacco firm destroyed papers. The Age (Melbourne, Vic) 23 Aug 2002. http://www.theage.com.au/articles/2002/08/22/ 1029114163418.html (Accessed 19 Sep 2003).

28 Wall C. Document disposal suspension notice. 4 May 1994. Philip Morris. Bates No. 2504099942/9943. http://legacy.library.ucsf.edu/tid/ yen $32 \mathrm{e} 00$

The editors would like to gratefully acknowledge the work of Associate Professor Ruth Malone from the University of California, San Francisco who acted as guest editor for this supplement during its preparation 